\title{
Nagy Nikolett: A spanyol pénzügyi igazgatás történeti hagyományai és szervezeti felépítése napjainkban
}

\begin{abstract}
Absztrakt
A tanulmány a spanyol pénzügyi igazgatáson belül a felelös minisztérium történeti kialakulását és fejlödését hivatott bemutatni. Amennyiben a szervezet célkitüzését kéne meghatározni, azt mondhatjuk, hogy célja az állam számára megteremtse a megfelelö bevételi forrásokat és egyben a társadalom müködtetője is legyen. A spanyol pénzügyminisztérium alapitása a Bourbon adminisztráció idejére vezethetö vissza, amikor az volt az elsödleges cél, hogy az országot az akkori igen súlyos válságból kivezessék, és a széttöredezett királyságokat egy központi irányitás alá vonják. Az minisztérium fejlödésében a spanyol örökösödési háború (1701-1714) jelentette a következö mérföldkövet. Ebben az idöszakban bár egységes kasztíliai irányitás alá terelték a pénzügyi folyamatokat, ám a Spanyol Korona továbbra is az elözö korokból megörökölt adósságok felszámolásával küzdött. A XIX. században Alejandro Mon y Menéndez (1801-1882) felismerte a változás szükségességét, amelyet elöször szabályozó intézkedések bevezetésével igyekezett elérni, majd a közvetlen és az indirektek bevételek csökkentésével. A kor másik kiemelkedö alakja Juan Bravo Murillo (1803-1873), aki a Mon-féle jogi háttérhez államigazgatási alapot adott a pénzügyi igazgatásnak. A Minisztérium stabilitását az 1950-es években nyerte el, amely egyrészt az ország nemzeti jövedelmének a növekedésével, másrészt a munkafolyamatok korszerüsitésével, gépesitésével és az adórendszer reformjával járt. Jelenleg a Minisztérium három fö egységre bontható: Pénzügyi Allamtitkárság, Költségvetési és Kiadások Államtitkársága és a Pénzügyi Helyettes Államtitkárságra. A tudományos életben megjelennek a tématerület feldolgozásai az 1988 óta megjelenö Tér, idö és alakulás címü éves kiadvány gondozásában. Az oktatásban nagy szerepe van a Nemzeti Távoktatási Egyetemnek, ahol mind a bevételi igazgatási, adó-és pénzügyi szakemberek képzése, továbbképzése történik Madridban és még másik négy tartományi székhelyen.
\end{abstract}

\section{Abstract}

This study aims to show the historical formation and development of the Ministry of Treasury in the field of finance administration. The main goal of the organization is to establish the appropriate incoming sources for the state, meanwhile it acts as the financial operator of the society. The Spanish Ministry of Treasury was founded in the era of the Bourbon administration when its primary goal was to bring out the country of the crisis and to direct the earlier shattered kingdoms under one central governance. In the development of the Ministry, the Spanish succession war (1701-1714) was the next milestone. During this period, the processes were brought under the control of a single Castile, but the Spanish Crown continued to struggle with the debt of earlier ages. In the 19th century, finance minister Alejandro Mon $y$ Menéndez (1801-1882) recognized the need for change, which he first sought to achieve through the introduction of regulatory measures and then the reduction of direct and indirect revenues. The other significant person of this era was Juan Bravo Murillo (1803-1873), who while being minister of finance provided the base of the public administration to the legal background established by Mon. The Ministry gained 
stability in 1950, which, on the one hand, was accompanied by an increase in national income and, on the other hand, the modernization, mechanization and reform of the tax system. Currently, the Ministry can be divided into three main units: The State Secretary for Finance, the StateSecretariat for Budget and Expenditure and the Deputy Secretary of State for Finance. For the academic communities, relevant studies have been published in the periodical of Space, Time and Evolution since 1988. The National University of Distance Education plays a major role in education, with training and further training programmes for the revenue, tax and finance professionals in Madrid and other four cities in the province.

\section{Bevezetés}

Ez a tanulmány a spanyol pénzügyminisztérium helyzetét, kialakulásának a folyamatát és jelenkori tagozódását mutatja be. A spanyol központi államigazgatás jelenleg tizenhét minisztériumra tagozódik. A 355/2018-as Királyi Rendelet értelmében a pénzügyekért felelős szervezet a Pénzügyminisztérium. ${ }^{402} \mathrm{~A}$ spanyol pénzügyi igazgatás a XIX. században szilárdult meg, majd ezt követően négy szakaszra osztható fejlődése. Elsőként 1900-1935 közötti időről beszélhetünk, amely során lefektették a tartományi szerkezetre épülő állami berendezkedés alapjait. Ez egy átmeneti állapot volt csak a liberális és a jóléti állam felé vezető úton. Ezt követően, 1940-1958-ig az önellátó gazdálkodásra berendezkedő diktatúra idején egyfajta visszalépésről beszélhetünk a pénzügyi igazgatás területén is. A harmadik szakaszban 1959-1975 között ismét egy átmentet láthatunk, viszont ebben a szakaszban a pénzügyi igazgatás állami funkciói már kiszélesednek a megindult gazdasági növekedésnek köszönhetően. Végül, az 1975 utáni korszak során lépett az ország a demokráciához és a jóléti államhoz vezető útra, ami a pénzügyi igazgatás fejlődését is befolyásolta. ${ }^{403}$

A pénzügyi igazgatási szervezet hatáskörei közül kiemelkednek a közpénzügyekkel kapcsolatos, valamint a költségvetéssel és az államkincstár kiadásaival összefüggésben elvégzendő feladatok, a pénzügyi rendszerek müködtetése, együttmüködés a tartományi és helyi igazgatással, szolgáltatások felügyelete, elektronikus ügyintézési folyamatok elősegítése, értékelése. Szintén a minisztérium feladatához tartozik az állami pénzügyi forrásokkal való hatékony gazdálkodás, költségvetési címek szerinti források elosztása, az állam gazdálkodásának és pénzügyi müködésének a szabályozása. A minisztérium működése során kiemelt figyelmet fordít arra, hogy racionalizálják az ügyintézési folyamatokat, újabb technikai megoldásokat vezessenek be a munkavégzés során az erőforrásokkal való takarékosság érdekében és ha szükséges, a szervezeti felépítésüket is hozzáigazítsák az új feladatokhoz, munkavégzési módszerekhez. ${ }^{404} \mathrm{~A}$ szervezet feladatai, erőforrásai és a küldetésének

\footnotetext{
402 355/2018. június 6-i Királyi Rendelet a minisztériumi hivatalok újraszervezéséről. Állami Hivatalos Lap 2018.06.07., szám: 138, kötet: 1, pp. 58722-58727. URL: https://boe.es/boe/dias/2018/06/07/pdfs/BOE-A-2018-7575.pdf.

${ }^{403}$ Comín, Francisco: El desarrollo del Estado del bienestar en España. Historia y política: Ideas, procesos y movimientos sociales, 1999/2. szám, pp. 7-8.

404 1113/2018. szeptember 7-i Királyi Rendelet, amely a Pénzügyminisztérium szervezti felépítését szabályozza. Állami Hivatalos Lap 2018. 09. 08., szám: 218, kötet: 1, pp. 87705-87743. URL cím: 355/2018. június 6-i Királyi Rendelet a minisztériumi hivatalok újraszervezéséről. Állami Hivatalos Lap 2018.06.07., szám: 138, kötet: 1, pp. 58722-58727. URL: https://boe.es/boe/dias/2018/06/07/pdfs/BOEA-2018-7575.pdf.
} 
megvalósítása érdekében alkalmazott módszerei $^{405}$ folyamatos változás, ideális esetben fejlődés alatt állnak. Hasonlóan ahhoz, ahogy a változás rendszeresen visszatérő igényét a katonai és a rendvédelmi szerveknél is megfigyelték kutatók, a pénzügyminisztérium, mint szervezet müködésével kapcsolatban is folyamatos kihívásokat támaszt az említett három tényező. A változtatás motorjai gyakran jól azonosíthatók, mint például a feladatrendszer minőségi, vagy mennyiségi módosulása, az erőforrások alkalmazása terén elvárt takarékosság vagy az új eszközök által megkövetelt új módszerek bevezetése. $^{406}$

\section{Történelmi visszatekintés}

\subsection{Kezdeti próbálkozások}

A pénzügyminisztérium megalapításának a gyökerei a Bourbon adminisztráció idejére vezethetők vissza. Az intézkedés egyfajta megoldásként szolgált az igen súlyos pénzügyi válság leküzdésére a Habsburgok uralkodása idején, mindemellett jó eszköz volt arra, hogy a régebbi, széttöredezett spanyol királyságokat központi irányítás alá tereljék. A klasszikus pénzügyminisztérium szervezete hagyományosan egy olyan szervezetrendszer volt, amely a Kasztíliai és Aragón koronától függetlenül müködött. Ennek nyomán az első ilyen intézménynek a Pénzügyi Tanácsot lehet tekinteni, amelyet 1523-ban alapítottak, majd 1658-ban újították meg. Az Aragón Korona az alábbi klasszikus tisztségekkel müködött: Főbíró (El baile general) ${ }^{407}$, Udvari Főmester (E1 Maestre Racional de la Corte $\left.{ }^{408}\right)$. Ezek a tisztségek az Aragón királyság fő tisztségei közé tartoztak a XVI és XVII század során. ${ }^{409}$

A spanyol örökösödési háború (1701-1714) folyamán a kasztíliai és aragón intézkedéseket eltörölték (1707 és 1716 között), majd minden hatáskört a kasztíliai udvar igazgatása vett át. Ettől a kortól számíthatjuk a pénzügyi igazgatás klasszikus intézményeinek müködésének életbe lépését csak úgy, mint a Tanács (El Consejo), a Számvitel, a Könyvelés (La Contaduría), a Főfelügyelöség (La Superintendencia) létrejöttét is. Kétség sem férhet hozzá, hogy ez az újfajta kasztíliai felosztás nem hozta meg a várt eredményeket, ugyanis a Spanyol Korona igen súlyos pénzügyi válságban volt a XVII. század óta a korábbi uralkodók alatt lecsökkent bevételek miatt. ${ }^{410}$

1754-től kezdve az Általános Kiadások Igazgatósága (La Dirección de Rentas Generales) igen fontos szerepet kapott abban, hogy ellenőrizze és racionalizálja a fő

${ }^{405}$ Az erőforrásokat és módszereket együtt képességeknek szokták hívni.

${ }^{406}$ Vö. például M. SzABÓ Miklós: Légiuralom-elmélet - légi fegyverkezés - a Magyar Királyi Légierő az 1930-as években. Mindentudás Egyeteme, IX. szemeszter, 2006.10.02. elérés 2019. július 6. URL: https://mindentudas.hu/300-mindentudas-k2-categories /kapcsolódó/linkek/7508-legiuralom-elmeletlegi-fegyverkezes-a-magyar-kiralyi-legiero-az-1930-as-evekben-link.html, és CSABA, Zágon: Experiences and spread of risk analysis in the law enforcement. In: CZENE-POLGÁR, Viktória; ZsÁMBOKINÉ, FICSKOVSZKY Ágnes (szerk.) Innováció, elektronizáció, tudásmenedzsment. Magyar Rendészettudományi Társaság Vám- és Pénzügyőri Tagozat, Budapest, 2018. pp. 47-57.

${ }^{407}$ CANGA ARGÜELLES, don Jose: Enciclopedia española de derecho y administración. Madrid, Imprenta de Diaz y compañía, 1852., pp. 391-393.

408 MAsiÁ de Ros, A.: El Maestre Racional en la Corona de Aragón. Una Pragmática de Juan II sobre dicho cargo. Hispania, 1950/10. szám, pp. 25-60.

${ }^{409}$ GARCÍA, David Alonso: Organización de la hacienda real y poder financiero a principios del siglo XVI. In: Bernal Rodríguez, Antonio Miguel (szerk.): Modernidad de España: apertura europea e integración atlántica. Madrid, Marcial Pons, Ediciones de Historia, 2017., pp. 687-700.

${ }^{410}$ López CAMPILlo, Rosa María: Daniel Defoe y la guerra de sucesión española. Tesis Doctoral. Ediciones de la Universidad de Castilla- La Mancha, Cuenca, 2010. pp. 119-139. 
bevételeket és kiadásokat, különösképpen a vámokból és a tartományoktól származó jövedelmeket. IV. Károly uralkodása alatt az országban ismét gazdasági válság következett be, amely politikai labilitást hozott a belpolitikai életben, amit aztán a francia forradalom csak tovább súlyosbított. A változások mind a közigazgatásban, mint a pénzügyi igazgatásban megmutatták hatásukat. Az egyik szervezeti változás például az volt, hogy az amerikai ügyekkel (gyarmatokkal) összefüggésben megszünt az Indiánok Általános Hivatalának Titkársága (La Secretaría del Despacho Universal de las Indias). ${ }^{411} \mathrm{Ez}$ a lépés arra engedett következtetni, hogy a Spanyol Királyság befolyása csökkent a tengerentúli gyarmati területeken.

A XVIII. század végére (1793) egy újabb háborús időszak vette kezdetét az országban, amely a következő század közepéig elhúzódott (1845). A Koronára nézve súlyos hatással volt ez az időszak, mert fokozatosan elvesztette az irányítást az amerikai érdekeltségei felett, amelynek hatása a XIX. századig megmaradt. A bevételek hiánya az állam eladósodását eredményezte, amelynek visszafordítására különböző intézkedésekkel próbálkoztak. Ide sorolhatjuk például a királyi utalványrendszer bevezetését, melynek célja az államadósság mértékének a stabilizációja volt annak érdekében, hogy elkerüljék az államcsődöt. ${ }^{412}$ 1795-ben eltörölték a Pénzügyek Főfelügyelőségét, amely magába foglalta az Államtitkárságot és a Hivatalt. 1808 és 1814 között egyidejűleg müködött két Pénzügyminisztérium - egy jozefinus és egy burbon - egészen a XIX. század végéig.

VII. Ferdinánd reformja a Titkárság szervezetére és müködésére irányult. Az uralkodó azt a célt tüzte ki, hogy egy jól működő egység jöjjön létre, amely kihúzza a pénzügyi igazgatást (és a Kincstárt) a háborús helyzet okozta katasztrofális helyzetből. Ennek keretében 1824-ben valósult meg a Kincstár Főigazgatóságának a megreformálása, azzal a céllal, hogy a költségvetési bevételek elosztó szerve legyen. 1836-ban az indiánok pénzügyeiért felelős szervek feloszlottak, majd ezzel egyidőben felmerült az igény a Törlesztésekért felelős Főigazgatóság megalapítására. Ezzel a döntéssel az állam bevételhez jutott a spanyolkatolikus egyháztól elkobzott vagyon révén. II. Izabella királynő uralkodása idején visszafordíthatatlanul elkezdődtek az alkotmányos reformok. Közpénzügyi folyamatokat indítottak el, amelyekkel stabilitást kívánták teremteni a gazdagság és a politika egyensúlyának helyreállításával, amelynek haszonélvezője elsősorban a feltörekvő polgárság lett. ${ }^{413}$

\subsection{A reform idöszaka}

1845-ben az adóztatási reformok Alejandro Mon y Menéndez (1801-1882) személyes nyomására valósultak meg, aki ekkor az Államtitkárság és Hivatal a kötelékébe tartozott. Ez a szerv közvetlen a király igazgatása alatt állt, ahol gyakran bizalmasai töltöttek be a kormányzás szempontjából kulcsfontosságú szerepet. Mon először 1837. december 16-tól 1838. szeptember 6-ig volt pénzügyminiszter; majd 1844. május 3-től 1846. február 12-ig ismét, ezt követően pedig, több alkalommal is

\footnotetext{
411 Portal Institucional Del Ministerio de Hacienda, Historia del Ministerio sz.n. és é.n. elérés: 2019.04.01. URL: http://www.hacienda.gob.es/esES/El\%20Ministerio/Paginas/Historia\%20del\%20Ministerio/Historia.aspx

${ }^{412}$ HERnÁNDEZ, Bernardo: La economía del siglo XVIII. In: GARCÍA CÁRCEL, Ricardo (szerk.): Historia de España del siglo XVIII: La España de los Borbones. España, Cátedra, 2002., pp. 283-317.

${ }^{413}$ Puyol MonTERo, José Martín: El consejo real de Castilla el el reinado de Fernando VII. Tesis Doctoral. Madrid, Universidad Complutense de Madrid, Facultad de derecho, 1992. pp. 269-514.
} 
betöltötte a miniszteri tisztséget. ${ }^{414} \mathrm{~A}$ reform igen nagy jelentőségünek bizonyult, hiszen véget vetett a „régi rezsimnek” egy jelentős egyszerüsítés révén. A Mon által elképzeltek szerint adót kellett fizetni az ingatlanértékesítéssel kapcsolatos szerződéseknél, a mezőgazdasági termelö, valamint a kereskedelmi tevékenységek után. Ezek a lépések mind a személyi jövedelemadó bevezetését késleltették. A Mon-féle reform új szervezeti felépítést kívánt meg ahhoz, hogy a gépezet alkalmazkodni tudjon az új körülményekhez. Szintén ez idő alatt valósult meg a hivatal jelenlegi székhelyére való átköltöztetése (a Királyi Vámházba, La Casa Real Aduana). A centralizált intézkedések további lépéseként mind a Titkárságot, és a Kincstárat, mind pedig a Jövedelmekért felelős főigazgatóságot igyekeztek központi igazgatóság alá vonni, ám ezek kezdetben még nagyfokú önállósággal rendelkeztek. ${ }^{415}$

Amennyiben Mon tekinthető technikai és jogi szempontból a modern pénzügyek meghonosítójának, akkor Juan Bravo Murillo (1803-1873) pedig annak államigazgatási alapjait fektette le. Murillo pénzügy- és fejlesztési miniszteri időszaka alatt látott napvilágot 1850-ben a könyvelésröl szóló törvény, ${ }^{416}$ amelyhez köthető a minisztérium, mint szakterminológia használatának elterjedése. Ez váltotta fel a korábban használatos Államtitkárság és Hivatal elnevezést. Murillo a bürokrácia elve szerint szervezte meg a hivatalt. Megerősítette a pénzügyminisztérium hatáskörét a főigazgatóságok felett. Müködésének idején olyan kulcsfontosságú szervezetek jöttek létre, mint a Közvetett és Közvetlen Adók Föigazgatóságai, a Könyvelési Főigazgatóság, az Adósságok Főigazgatósága és a Vitás Ügyekkel Foglalkozó Főigazgatóság. Szintén az ő érdemei közé sorolható a Letétek Pénztárának a létrehozása (La Caja General de Depósitos ${ }^{417}$ ), amely kezdetben az államot szabadította fel a banki függőségek alól, mert a banki hitelezés helyett a pénztár kötvény kibocsájtással próbálta megoldani az állam finanszírozási gondjait. Végül ez az intézkedés mégsem hozta el a várt eredményeket. ${ }^{418}$

$\mathrm{Az}$ ország fejlődése során újabb és újabb gazdasági válságokkal kellett szembenézni, ám ezek leküzdésére az aktuális miniszterek, Figuerola 1869, Navarro Reverter 1895, Fernández Villaverde 1902-1903 újabb intézkedései sem bizonyultak elegendőnek. A XX. század elején Villaverde elképzelései szerint hatékonyabb igazgatási rendszert vezettek be, amely az adóztatási reformhoz igazodott. ${ }^{419}$

1923 és 1925 között Miguel Primo de Rivera tábornok vezetésével katonai autoriter rendszer alakult ki Spanyolországban, melynek célja a marokkói szeparatista törekvések elfojtása és az 1920-ban kitört spanyol-marokkói függetlenségi háború megnyerése volt. A katonai célok érdekében a minisztérium hatásköreinek csökkentése zajlott le. A 20-as években fellendült a gazdaság, aminek 29-ben a gazdasági világválság vetett véget, egyben magával hozva a spanyol állam fizetésképtelenségét is.

\footnotetext{
${ }^{414}$ SAMPEDRO, José Luis -VAL, Fernando Alos Merry: Ministros de Hacienda y de Economía de 1700 a 2005: tres siglos de historia. Madrid, Ministerio de Economía y Hacienda, 2005. pp. 190-220.

${ }^{415}$ VAllejo PousAdA, Rafael: Alejandro Mon, un reformador económico. In. COMÍn, Francisco-MARTíN ACEÑa, Pablo -VALlejo POUSADA, Rafael (editores): La Hacienda por sus ministros: la etapa liberal de 1845 a 1899. Zaragoza, Prensas Universitarias de Zaragoza, 2006. pp. 57-90.

${ }^{416}$ SAMPEDRO-VAL: i. m. 2005.

${ }^{417}$ Tesoro Público, Bienvenido a la Caja General de Depósitos sz.n. és é.n. elérés: 2019.04.12. URL: http://www.tesoro.es/caja-general-de-depositos/caja-general-de-depositos

${ }^{418}$ Pro, Juan: Bravo Murillo: el abogado en Hacienda. In: CoMín, Francisco-MArTín Aceña, Pablo VALLEJo POUSADA, Rafael (editores): La Hacienda por sus ministros: la etapa liberal de 1845 a 1899. Zaragoza, Prensas Universitarias de Zaragoza, 2006. pp. 133-170.

419 Portal Institucional Del Ministerio de Hacienda, Historia del Ministerio sz.n. és é.n. elérés: 2019.04.01. URL: http://www.hacienda.gob.es/esES/E1\%20Ministerio/Paginas/Historia\%20del\%20Ministerio/Historia.aspx
} 
Az erősen polarizált spanyol társadalomban a növekvő szociális, gazdasági és politikai feszültségek oda vezettek, hogy az 1931-es helyhatósági választásokat republikánus pártok nyerték. Kikiáltották a második köztársaságot és a király külföldre menekült. Az 1936-ben kitört és 1939-ig elhúzódó spanyol polgárháború idején a pénzügyminisztérium egy olyan eszközzé alakult át, amelynek elsődleges feladata a háború katonai kiadásainak finanszírozásához a források megteremtése lett attól függően, hogy a szembenálló felek közül a minisztérium éppen melyik oldal ellenőrzése alatt állt. ${ }^{420}$

\subsection{A modern kor sajátosságai}

A polgárháborút megnyerő Francisco Franco Spanyolország katonai diktátora lett. Hatalma megszilárdítását követően Franco Spanyolországa hivatalosan nem vett részt hadviselő félként a második világháborúban ${ }^{421}$. A világháborút követően az ország politikai, kulturális és gazdasági értelemben azonban elszigetelődött, a megmaradt afrikai gyarmatait pedig elveszítette, amely súlyosan befolyásolta a gazdaság viszonyait is.

E turbulens időszakot követően 1957-ben szervezetében ismét stabilizálódott a pénzügyminisztérium. Újabb adóügyi reformok sora vette kezdetét, amelyeknek köszönhetően a nemzeti jövedelem emelkedni kezdett. Két évvel később megalakult a Kincstár és a Közköltségek Altitkársága (La Subsecretaría de Tesoro y Gastos Públicos) amelynek fó feladata az állami pénzügyi javak ellenőrzése és a költségvetés összeállítása volt. Ettől a korszaktól beszélhetünk arról, hogy az ügyintézési folyamatokat gépesítették és az adózók számára lehetőség nyílt az adóügyi információk tanulmányozására. 1963-64 között zajlott Mariano Navarro Rubio vezetése alatt került sor az általános adóztatási törvények bevezetésére és ezzel egyidejüleg az adózási rendszer újabb megreformálására. Ennek első lépéseként új forgalmi adókat vezettek be a gazdasági társaságok által forgalomba hozott áruk és szolgáltatásokkal összefüggésben. 1967-ben gazdasági megszorítások léptek életbe. Ennek egyik hangsúlyos pontja az volt, hogy az adóigazgatás hatékonyságát növeljék és magát a minisztériumot alakítsák át különös tekintettel annak felépítésére és müködésére. A szervezeti változások során megszüntettek bizonyos szervezeti egységeket, melyek közül ki lehet emelni a Kincstár és a Közköltségek Altitkárságának (La Subsecretaría de Tesoro y Gastos Públicos) az eltörlését.

Franco tábornok 1975-ös halálával véget érő diktatúra utolsó éveiben óvatos politikai és gazdasági liberalizációs folyamatok zajlottak az országban, ami felfuttatta az idegenforgalmat.

Az 1970-es évektől beszélhetünk a reform korszakának egyik legintenzívebb időszakáról, ugyanis 1973-76 helyzeték le a modern pénzügyi igazgatás alapjait, az adóztatási rendszer fö pontjait, amelyekhez az 1977-ben a költségvetési törvény, azonnali adóreformok járultak hozzá, amelyek már az alkotmányozási folyamat során az 1978-ban elfogadott új alkotmányt üdvözölték. Az alkotmányos monarchia kormányformát öltő ország döntéshozóinak olyan tényezőkkel kellett számolniuk, mint a munkanélküliség, az infláció, a külső adósságok, a közszféra eróziója és a befektetések hiánya, amelyet az 1973-as olajválság tovább súlyosbított. Ezen

\footnotetext{
${ }^{420}$ QUIROGA FERnÁNDEZ DE SoTO, Alejandro: La idea de España en los ideólogos de la dictatura de Primo de Rivera el discurso católico-fascista de José Pemartín. Revista de Estudios Políticos (Nueva Época), 2000/108. szám, pp. 1-27.

${ }^{421}$ Spanyol „önkéntesek” azonban harcoltak a tengelyhatalmak oldalán a Szovjetunió ellen.
} 
kulcsfontosságú tényezők rendezésére az államigazgatás újratervezése vált ismét sürgető tényezővé. Az intézkedések keretében hozták létre a Kormány Másodhelyettesi Elnökségét (La Vicepresidencia Segunda del Gobierno) a gazdasági ügyek kezelésére. 1982-ben olvadtak össze a pénzügyekért, a gazdaságért és a kereskedelemért felelős hivatalok a Gazdasági Ügyekért Felelős Minisztériumban. Ez egy olyan központi irányítású szerv lett, amely számos hatáskört próbált ötvözni: megalkotta a fó irányvonalakat általános politikai gazdasági vonalon, valamint olyan rövid- és középtávú terveket készített, amelyek az ország gazdasági fejlődését szolgálták. ${ }^{422}$

A pénzügyi igazgatás alapvető tevékenysége arra vezethető vissza, hogy a kormányzás számára megteremtse a megfelelő bevételi forrásokat és közvetlenül az állam, közvetve pedig a társadalom müködésének pénzügyi feltételeit biztosítsa. ${ }^{423} \mathrm{~A}$ minisztérium tehát egy olyan szerv, amely garantálni tudja az állami bevételek elosztását és helyes felhasználást a közigazgatás keretein belül. Az elv itt is ugyanaz volt, mint más kormányzati szervezeteken belül: a hatáskörök megosztása és új technológiák hatékony felhasználása a célok elérése érdekében, miközben arra törekszenek, hogy egyszerüsítsék, gyorsítsák az ügyintézési folyamatokat. A hivatali állomány számára olyan munkaeszközöket bocsájtottak rendelkezésre, illetve munkakörülményeket teremtettek, amelyeknek köszönhetően a képességeik, munkájuk szakmai színvonala és ismereteik folyamatosan növekedhessék, illetve bővüljön, amely végül egybe esik a közszolgálat érdekeivel. ${ }^{424} \mathrm{~A}$ spanyol pénzügyi igazgatásban például az 1913-tól alkalmaztak írógépeket (az elsőket 1900-tól, majd 20 évvel később széles körben elterjedt), 1924-től professzionális gépírókat, emellett 1930-tól csak úgy jelentkezhettek munkavállalók a szervezet kötelékébe, ha tudtak gépírni. Az 1960-as évtizedben jelentek meg az akkori időben már korszerünek tekinthető számítógépek, de bő egy évtizeddel később bevezették a munkavégzési folyamatokba a személyi számítógép alkalmazását, amely mára már elengedhetetlenül szükséges mindenütt, és ez a legelterjedtebb munkaeszköz. ${ }^{425}$ Ennek megfelelően a munkavállalókkal szemben a belépéstől kezdve elvárás a számítógépes alapismeretek megléte.

\section{A Minisztérium felépítése}

A Minisztérium jelenlegi felépítését az 1113/2018 szeptember 7-i királyi rendelet szabályozza. A szervezet három főegységre, a Pénzügyi Államtitkárságra (La Secretaría de Estado de Hacienda), a Költségvetési és Kiadások Államtitkárságára (La Secretaría de Estado de Presupuestos y Gastos) és a Pénzügyi Helyettes Államtitkárságra (La Subsecretaría de Hacienda) tagozódik, amelyek további alárendelt egységekre is bonthatók. Ebben a fejezetben röviden ismertetem a föegységek által ellátott feladatokat.

422 Portal Institucional Del Ministerio de Hacienda, Historia del Ministerio sz.n. és é.n. elérés: 2019.04.01. URL: http://www.hacienda.gob.es/esES/E1\%20Ministerio/Paginas/Historia\%20de1\%20Ministerio/Historia.aspx

423 355/2018. június 6-i Királyi Rendelet a minisztériumi hivatalok újraszervezéséről. Állami Hivatalos Lap 2018.06.07., szám: 138, kötet: 1, pp. 58722-58727. URL: https://boe.es/boe/dias/2018/06/07/pdfs/BOE-A-2018-7575.pdf.

${ }^{424} 1887 / 2011$ december 30-i Királyi Rendelet, amely a minisztériumi hivatalok alapvető szervezeti felépítését szabályozza. Állami Hivatalos Lap 2011.12.31., szám: 315, kötet: 1, pp. 146666-146679. URL: https://www.boe.es/boe/dias/2011/12/31/pdfs/BOE-A-2011-20644.pdf.

${ }^{425}$ Portal Institucional del Ministerio de Hacienda, Historia del Ministerio sz.n. és é.n. elérés: 2019.04.01. URL: 


\subsection{Pénzügyi Államtitkárság (La Secretaría de Estado de Hacienda)}

Ennek az egységnek a tevékenységi körébe tartoznak a fiskális politikával összefüggő feladatok csak úgy, mint az adóztatási rendszer megtervezése és alkalmazása, az adóból és más költségvetési forrásokból származó bevételek előrejelzése és elemzése, az ingatlanok nyilvántartása, ezen belül pedig a telekkönyvekkel kapcsolatos ügyintézési folyamatok irányítása és végrehajtása különös tekintettel a szabályozás, engedélyezés, felügyelet, irányítás. Szintén ide tartozik az állami szerencsejátékokkal összefüggő tevékenységek felügyelete. Az államtitkárság az alábbi öt egységre tagolódik:

- Tartományi és Helyi Folyósítások Főtitkársága,

- Adóügyi Főigazgatóság (La Dirección General de Tributos),

- Telekkönyvi Föigazgatóság (La Dirección General del Catastro),

- Gazdasági Adminisztratív Központ Bírósága (El Tribunal EconómicoAdministrativo Central),

- Szerencsejáték szabályozásának Főigazgatósága (La Dirección General de Ordenación del Juego). ${ }^{426}$

\subsection{Költségvetés és Kiadások Allamtitkársága (La Secretaría de Estado de Presupuestos y Gastos)}

Az államtitkárság alapvetően a közszféra költségvetési forrásainak megtervezésével, kialakításával foglalkozik. Ehhez kapcsolódóan a személyügyi kiadásokkal is itt foglalkoznak, továbbá feladataik érintik az európai uniós forrásokat, az egyéb regionális kezdeményezéseket is, különös tekintettel azokra, amelyek regionális gazdaságpolitikai célokat befolyásolnak. Emellett nyomon követik azokat az intézkedési folyamatokat, eljárásokat az európai uniós költségvetést érintően, amelyekben spanyol érintettség állapítható meg. Ez az államtitkárság felelős a költségvetésben meghatározottak betartatásáért, és az államadósság kezeléséért, amelynek a pénzügyi stabilitása miatt különösen fontos. A szervezet alárendeltségében az alábbi egységek müködnek:

- Költségvetési Főigazgatóság (La Dirección General de Presupuestos),

- Személyügyért és Nyugdíjért felelős Főigazgatóság (La Dirección General de Costes de Personal y Pensiones Públicas),

- Európai Forrásokat Kezelő Főigazgatóság (La Dirección General de Fondos Europeos). ${ }^{427}$

\subsection{Pénzügyi Helyettes Államtitkárság (La Subsecretaría de Hacienda)}

Tevékenységének keretrendszerét a 40/2015. október 1-i törvény adja, amely a közszféra jogi rendszerét szabályozza. A 63. cikk alapján a helyettes államtitkárságnak az irányítási és felügyeleti jogkörei vannak. ${ }^{428}$ Itt készül az állami költségvetési terv, innen irányítják a minisztérium közös információfeldolgozó és elektronikus ügyintéző

\footnotetext{
${ }^{426}$ 1113/2018. szeptember 7-i Királyi Rendelet, amely a Pénzügyminisztérium szervezti felépítését szabályozza. Állami Hivatalos Lap 2018. 09. 08., szám: 218, kötet: 1, pp. 87705-87743. URL: https://www.boe.es/buscar/act.php?id=BOE-A-2018-12265.

${ }^{427}$ Uo.

42840/2015 október 1-jei Törvény a Közszféra jogi rendszeréről. Állami Hivatalos Lap 2015.10.02., szám: 236, kötet: X, pp. X-X. URL: https://www.boe.es/buscar/pdf/2015/BOE-A-2015-10566-consolidado.pdf.
} 
rendszereit, illetve ezek fejlesztését és karbantartását. A helyettes államtitkárság alárendeltségében az alábbi szervek múködnek:

- Technikai Fötitkárság (La Secretaría General Técnica),

- Állami Vagyon Főigazgatósága (La Dirección General del Patrimonio del Estado),

- Főfelügyelőség (La Inspección General),

- és a Szerződések Központosításának és Racionalizálásának Főigazgatósága (La Dirección General de Racionalización y Centralización de la Contratación). ${ }^{429}$

\section{1. táblázat: A Pénzügyminisztérium szervezeti felépítése}

\begin{tabular}{|c|c|c|}
\hline Főegységek & Alegységek & Ellátandó feladatok \\
\hline \multirow[t]{5}{*}{ Pénzügyi Államtitkárság } & $\begin{array}{ll}\text { Tartományi és } & \text { Helyi } \\
\text { Folyósítások Főtitkársága } & \end{array}$ & $\begin{array}{l}\text { a tartományok és az autonóm } \\
\text { jogállású városokkal összefüggő } \\
\text { finanszírozások biztosítása }\end{array}$ \\
\hline & Adóügyi Főigazgatóság & $\begin{array}{l}\text { az adóztatási rendszerrel } \\
\text { kapcsolatos tevékenységek }\end{array}$ \\
\hline & Telekkönyvi Főigazgatóság & $\begin{array}{ll}\text { széleskörü } & \text { földhivatali } \\
\text { szolgáltatások } & \end{array}$ \\
\hline & $\begin{array}{l}\text { Gazdasági-Adminisztratív } \\
\text { Központ Bírósága }\end{array}$ & $\begin{array}{l}\text { az ügyintézéssel vagy gazdasági } \\
\text { kérdésekkel összefüggő ügyek } \\
\text { tárgyalása }\end{array}$ \\
\hline & $\begin{array}{l}\text { Szerencsjáték Szabályozásának } \\
\text { Főigazgatósága }\end{array}$ & $\begin{array}{l}\text { bármilyen } \\
\text { szervezésének } \\
\text { lebonyolításának a felügyeletencsejáték }\end{array}$ \\
\hline \multirow[t]{3}{*}{$\begin{array}{l}\text { Költségvetés és Kiadások } \\
\text { Államtitkárságára }\end{array}$} & Költségvetési Főigazgatóság & $\begin{array}{l}\text { az éves kiadások és bevételek } \\
\text { figyelemmel kisérése és } \\
\text { megtervezni a következő évre a } \\
\text { költségvetést }\end{array}$ \\
\hline & $\begin{array}{l}\text { Személyügyért és Nyugdíjért } \\
\text { felelös Főigazgatóság }\end{array}$ & $\begin{array}{lll}\text { a közszektor forrásainak az } \\
\text { elosztásának a felügyelete }\end{array}$ \\
\hline & $\begin{array}{ll}\text { Európai forrásokat } & \text { Kezelö } \\
\text { Főigazgatóság } & \\
\end{array}$ & $\begin{array}{l}\text { az európai uniós kötelezettségek } \\
\text { teljesítése }\end{array}$ \\
\hline \multirow[t]{4}{*}{$\begin{array}{ll}\text { Pénzügyi } & \text { Helyettes } \\
\text { Államtitkárság } & \end{array}$} & Technikai Főtitkárság & $\begin{array}{l}\text { a mindenkori miniszter által } \\
\text { irányított szervezet kiszolgálása, } \\
\text { a hivatal munkafolyamatainak a } \\
\text { kézben tartása }\end{array}$ \\
\hline & Állami Vagyon Főigazgatósága & $\begin{array}{l}\text { ügyintézés, felkutatás, nyomozás } \\
\text { az állam javainak a megvédése } \\
\text { érdekében }\end{array}$ \\
\hline & Főfelügyelöség & $\begin{array}{l}\text { a helyettes államtitkárság vezetö } \\
\text { szerepét tölti be }\end{array}$ \\
\hline & $\begin{array}{lr}\text { A } & \text { szerződések } \\
\text { központosításának } & \text { és } \\
\text { racionalizálásának } & \text { a } \\
\text { Főigazgatósága } & \end{array}$ & $\begin{array}{l}\text { tanulmányozás, tervezés, } \\
\text { előkészítés, nyomon követés }\end{array}$ \\
\hline
\end{tabular}

Forrás: az 1113/2018. szeptember 7-i Királyi Rendelet alapjánsaját szerkesztés

429 1113/2018. szeptember 7-i Királyi Rendelet, amely a Pénzügyminisztérium szervezti felépítését szabályozza. Állami Hivatalos Lap 2018. 09. 08., szám: 218, kötet: 1, pp. 87705-87743. URL: https://www.boe.es/buscar/act.php?id=BOE-A-2018-12265. 


\section{Képzés}

Spanyolországban jelenleg a pénzügyekkel kapcsolatos képzést a Nemzeti Távoktatási Egyetem (Universidad Nacional de Educación a Distancia, a továbbiakban: UNED) indít, amelybe szerveztileg betagozódott az Adótanulmányok Intézete (El Instituto de Estudios Fiscales, a továbbiakban: IEF). A képzés központja Madridban van, de ezen kívül egyéb regionális kirendeltségek is müködnek, mint például Coruñában, Barcelonában, Sevillában és Valenciában. A képzés keretén belül olyan szakembereket oktatnak, akik a pénzügyi igazgatásban és az arra vonatkozó továbbképzések területén tudnak elhelyezkedni. Az IEF a Minisztérium célkitüzéseinek megfelelően ellátja mind a pénzügyi, mind az adóügyi hivatalnokok képzését Spanyolországban és az ún. iberoamerikai államokban a vonatkozó nemzetközi kölcsönös segítségnyújtási megállapodás alapján. Emellett az egyetem bekapcsolódik bilaterális megállapodások alapján számos más országot érintő kutatás-fejlesztési projektbe is. ${ }^{430}$

A pénzügyekkel kapcsolatos témák kutatási eredmények tudományos igényü publikálása az UNED „Tér, idő és alakulás” címü 1988 óta megjelenő periodikájában és más szaklapokban történik. A publikációk között a kezdetektől fogva megjelennek a vámmal és/vagy adóval kapcsolatos tanulmányok. A lap első számában például Pegerto Saavedra írt az elmúlt rendszer idején Galicia tartomány bevételi ügyeiröl ${ }^{431}$ vagy Laureano M. Rubio Pérez készített tanulmányt Leon tartományban az adókból, jövedékekből és a hitelezői fogásokból származó bevételekből a XVII-XVIII. század közötti Astroga város példáján keresztül bemutatva. ${ }^{432}$ Számos tanulmány foglalkozik a pénzügyi igazgatás történetével, mint például Javier Donézar: A Királyi Pénzügyörség helyi és a királyság vonatkozásában hozott rendelkezései 1749-ben. ${ }^{433}$ Elemzések foglalkoznak az ország fejlődéséhez kapcsolódó pénzügyi igazgatási kérdésekkel, mint Yovana Celaya Nández: Helyi adók az Új Spanyolországban ${ }^{434}$ címü cikke, illetve a bankjegyekkel és érmékkel kapcsolatos ügyekkel, mint például María Teresa Muñoz Serrulla: Hamisítás, külföldi pénznemek bevezetése és a nemesfémkitermelés: az örökösödési háború és annak következményei a félszigeten című munkája. ${ }^{435}$ Fentiekből is látható, hogy a spanyol tudományos közösség élénken foglalkozik a pénzügyi igazgatáshoz kapcsolódó témák kutatásával, elemzésével és eredményeiket elsősorban spanyol nyelven, de egyre szélesebb körben angolul, franciául és más nyelveken is publikálják. Bár e cikk keretein ez túlmutat, egy következő tanulmányban elemezni kívánom, hogy melyek a spanyol tudományos közélet kutatási súlypontjai; milyen

\footnotetext{
${ }^{430}$ Portal Institucional del Ministerio de Hacienda, La Escuela de Hacienda Pública, sz.n. és é.n. (letöltve: 2019.05.02.) URL cím: http://www.hacienda.gob.es/esES/Areas\%20Tematicas/Formacion/Paginas/La\%20Escuela\%20de\%20Hacienda\%20Publica.aspx.

${ }^{431}$ SAAVEDRA, Pegerto: Aportación al estudio de las rentas provinciales de la Galicia del Antiguo Régimen. Revista de la Facultad de Geografía e Historia, 1989/4. szám, pp. 585-622.

${ }^{432}$ Rubio PÉREZ, M. Laureano: Deudores, rentistas y prácticas crediticias en la sociedad leonesa. El ejemplo de la ciudad de Astorga en los siglos XVII y XVIII. Revista de la Facultad de Geografía e Historia, 1989/4. szám, pp. 551-584.

${ }^{433}$ DonÉZAR DíEZ DE UlzurRun, Javier M.: Los decretos de la Real Hacienda de 1749, los poderes locales y la representación del reino, Espacio, Tiempo y Forma, Serie IV. Historia Moderna, 1999/12. szám, pp. 297-320.

${ }^{434}$ CElAYA NÁNDEZ, Yovana: Impuestos locales en Nueva España, Espacio, Tiempo y Forma, Serie IV. Historia Moderna, 2014/27. szám, pp. 37-59.

${ }^{435}$ MuÑoz SERRULlA, María Teresa: Falsificación, introducción de moneda extranjera y extracción de metales la Guerra de Sucesión y sus consecuencias monetarias en la Península. Espacio, Tiempo y Forma, Serie IV. Historia Moderna, 2016/29. szám, pp. 223-242.
} 
lapokban és milyen témákban és mely tudományterületeket érintően publikálnak a spanyol kollégák? Ez adhat pontosabb képet a spanyol viszonyok megértéséhez.

\section{5. Összegzés}

A tanulmány során a spanyol pénzügyminisztérium kialakulását és fejlődését mutattam be. Történelmi események és politikai változások jelentősen befolyásolták, alakították, fejlesztették a szervezet felépítését és a müködés szabályait. Az egységes pénzügyi igazgatás igénye Spanyolországban a XIX. században jelenik meg, amikor az újításoknak köszönhetően mind a szükséges adóztatási reformok és ahhoz kapcsolódóan a pénzügyi igazgatás szervezete is megújulnak. A következő században már a minisztérium belső folyamatai, munkaeszközei is tovább fejlödtek, melynek során mindig szem előtt tartották, hogy az adott kor technológiai vívmányait isbeillesszék a munkafolyamtokba. A tanulmányban vizsgált időszak során nyilvánvaló kapcsolat mutatható ki a szervezet feladatai, erőforrásainak alkalmazása, vagyis a módszerei és az ehhez illeszkedő szervezeti megoldások között. A változásokat a szervezet müködése szempontjából keletkező kockázatok kezelésének igénye tartotta mozgásban, amelyek során felhasználták a technikai vívmányok által kínált új lehetőségeket is. Szembeszökő, hogy a szervezet, az erőforrás és a módszer kategóriák szerint leírt három tényező folyamatosan változott és egyikük változása minden esetben hatást gyakorolt a másik két elemre is. Ezek aztán újabb kölcsönhatásba léptek egymással és ez tulajdonképpen megállás nélkül folytatódott hasonlóan ahhoz, ahogy M. Szabó Miklós akadémikus hivatkozott előadásában ${ }^{436}$ a katonai szervezetekre, illetve Csaba Zágon a rendvédelmi szervezetek kockázatkezelésére vonatkozóan leírta. ${ }^{437}$

A jelenlegi minisztérium feladatai igen komplexek, hiszen a szervezet nem csupán az adókkal kapcsolatos szabályok, a szükséges fejlesztések és reformok előkészítését és megvalósítását végzi, hanem olyan járulékos feladatokat is ellát, mint a költségvetési tervezés, az ingatlannyilvántartás, és a szerencsejátékok felügyelete. Ezeket kiegészíti az Európai Unióból származó források kezelése is, amelyek jelentős mértékben érintik az ország gazdaságpolitikáját. A pénzügyi igazgatáshoz tartozó területeken az oktatás és a tudományos kutatás terén fontos szerepet tölt be a Nemzeti Távoktatási Egyetem, amely egyfajta katalizátor szerepet tölt be az érintett szakmaitudományos közösség, illetve az általuk a pénzügyi igazgatóság előtt álló problémákról történő tudományos gondolkodás szempontjából.

\section{Felhasznált irodalom}

[1] 40/2015. október 1-jei Törvény a Közszféra jogi rendszeréről. Állami Hivatalos Lap 2015.10.02., szám: 236, kötet: X, pp. X-X. URL: https://www.boe.es/buscar/pdf/2015/BOE-A-2015-10566-consolidado.pdf.

[2] 355/2018. június 6-i Királyi Rendelet a minisztériumi hivatalok újraszervezéséről. Állami Hivatalos Lap 2018.06.07., szám: 138, kötet: 1, pp. 58722-58727. URL: https://boe.es/boe/dias/2018/06/07/pdfs/BOE-A-20187575.pdf.

[3] 1113/2018. szeptember 7-i Királyi Rendelet, amely a Pénzügyminisztérium szervezti felépítését szabályozza. Állami Hivatalos Lap 2018. 09. 08., szám:

\footnotetext{
${ }^{436}$ M. SZABÓ Miklós: i. m. 2006.

${ }^{437}$ CSABA Zágon: i. m. 2018.
} 
218, kötet: 1, pp. 87705-87743. URL: https://www.boe.es/buscar/act.php?id=BOE-A-2018-12265.

[4] 1887/2011. december 30-i Királyi Rendelet, amely a minisztériumi hivatalok alapvető szervezeti felépítését szabályozza. Állami Hivatalos Lap 2011.12.31., szám: 315, kötet: 1, pp. 146666-146679. URL: https://www.boe.es/boe/dias/2011/12/31/pdfs/BOE-A-2011-20644.pdf.

[5] CANGA ARgÜElles, don Jose: Enciclopedia española de derecho y administración. Madrid, Imprenta de Diaz y compañía, 1852.

[6] Celaya NÁndez, Yovana: Impuestos locales en Nueva España, Espacio, Tiempo y Forma,Serie IV. Historia Moderna, 2014/27. szám, pp. 37-59.

[7] Comín, Francisco: El desarrollo del Estado del bienestar en España. Historia y política: Ideas, procesos y movimientos sociales, 1999/2. szám, pp.7-8.

[8] CSABA, Zágon: Experiences and spread of risk analysis in the law enforcement. In: CZene-Polgár, Viktória; ZsÁmbokiné, FicSKOvsZKY Ágnes (szerk.) Innováció, elektronizáció, tudásmenedzsment. Magyar Rendészettudományi Társaság Vám- és Pénzügyőri Tagozat, Budapest, 2018. pp. 47-57.

[9] DonÉZAR DíEz de UlzurRun, Javier M.: Los decretos de la Real Hacienda de 1749, los poderes locales y la representación del reino, Espacio, Tiempo y Forma, Serie IV. Historia Moderna, 1999/12. szám, pp.297-320.

[10] GARCÍA, David Alonso: Organización de la hacienda real y poder financiero a principios del siglo XVI. In: BERNAL RodRíGUEZ, Antonio Miguel (szerk.): Modernidad de España: apertura europea e integración atlántica. Madrid, Marcial Pons, Ediciones de Historia, 2017., pp. 687-700.

[11] HERnÁNDEZ, Bernardo: La economía del siglo XVIII. In: GARCÍA CÁRCEL, Ricardo (szerk.): Historia de España del siglo XVIII: La España de los Borbones. España, Cátedra, 2002., pp. 283-317.

[12] LóPez CAMPILlo, Rosa María: Daniel Defoe y la guerra de sucesión española. Tesis Doctoral. Ediciones de la Universidad de Castilla- La Mancha, Cuenca, 2010.

[13] M. SzABó Miklós: Légiuralom-elmélet - légi fegyverkezés - a Magyar Királyi Légierő az 1930-as években. Előadás. Mindentudás Egyeteme, Budapest, 2006.10.2. (letöltve: 2019. július 6.) URL: https://mindentudas.hu/300mindentudas-k2-categories $\sim$ kapcsolódó/linkek/7508-legiuralom-elmelet-legifegyverkezes-a-magyar-kiralyi-legiero-az-1930-as-evekben-link.html

[14] MASí́ DE Ros, A.: El Maestre Racional en la Corona de Aragón. Una Pragmática de Juan II sobre dicho cargo. Hispania, 1950/10. szám, pp. 25-60.

[15] MuÑoz SERrulla, María Teresa: Falsificación, introducción de moneda extranjera y extracción de metales la Guerra de Sucesión y sus consecuencias monetarias en la Península. Espacio, Tiempo y Forma, Serie IV. Historia Moderna, 2016/29. szám, pp. 223-242.

[16] Portal Institucional del Ministerio de Hacienda, Historia del Ministerio sz.n. és é.n. (letöltve: 2019.04.01.) URL: http://www.hacienda.gob.es/esES/El\%20Ministerio/Paginas/Historia\%20del\%20Ministerio/Historia.aspx

[17] Portal Institucional del Ministerio de Hacienda, La Escuela de Hacienda Pública, sz.n. és é.n. (letöltve: 2019.05.02.) URL: http://www.hacienda.gob.es/esES/Areas\%20Tematicas/Formacion/Paginas/La\%20Escuela\%20de\%20Hacienda \%20Publica.aspx

[18] Pro, Juan: Bravo Murillo: El abogado en Hacienda. In: Comín, FranciscoMartín Aceña, Pablo -VAllejo PousAda, Rafael (editores): La Hacienda por 
sus ministros: la etapa liberal de 1845 a 1899. Zaragoza, Prensas Universitarias de Zaragoza, 2006. pp. 133-170.

[19] PuyOl Montero, José Martín: El consejo real de Castilla el el reinado de Fernando VII. Tesis Doctoral. Madrid, Universidad Complutense de Madrid, Facultad de derecho, 1992.

[20] Rubio PÉREZ, M. Laureano: Deudores, rentistas y prácticas crediticias en la sociedad leonesa. El ejemplo de la ciudad de Astorga en los siglos XVII y XVIII. Revista de la Facultad de Geografia e Historia, 1989/4. szám, pp. 551584.

[21] SAAVEDRA, Pegerto: Aportación al estudio de las rentas provinciales de la Galicia del Antiguo Régimen. Revista de la Facultad de Geografía e Historia, 1989/4. szám, pp. 585-622.

[22] SAmpedro, José Luis -VAL, Fernando Alos Merry: Ministros de Hacienda y de Economía de 1700 a 2005: tres siglos de historia. Madrid, Ministerio de Economía y Hacienda, 2005. pp. 190-220.

[23] Tesoro Público, Bienvenido a la Caja General de Depósitos sz.n. és é.n. (letöltve: 2019.04.12.) URL: http://www.tesoro.es/caja-general-dedepositos/caja-general-de-depositos

[24] Quiroga Fernández DE Soto, Alejandro: La idea de España en los ideólogos de la dictatura de Primo de Rivera el discurso católico-fascista de José Pemartín. Revista de Estudios Políticos (Nueva Época), 2000/108. szám, pp. 1-27.

[25] VAllejo PousadA, Rafael: Alejandro Mon, un reformador económico. In. Comín, Francisco-MARTín ACEÑA, Pablo -VALlejo PousAdA, Rafael (editores): La Hacienda por sus ministros: la etapa liberal de 1845 a 1899. Zaragoza, Prensas Universitarias de Zaragoza, 2006. pp. 57-90.

Lektorálta: Sallai János Prof. Dr. tanszékvezető egyetemi tanár Nemzeti Közszolgálati Egyetem, Rendészettudományi Kar Rendészettörténeti Tanszék sallai.janos@uni-nke.hu és Csaba Zágon Dr. PhD. adjunktus Nemzeti Közszolgálati Egyetem Rendészettudományi Kar Vám- és Pénzügyőri Tanszék csaba.zagon@uni-nke.hu 